\title{
OKUL ÖNCESİ DÖNEM ÇOCUKLARININ BENLİK KAVRAMI VE EBEVEYN TUTUMLARI ARASINDAKİ İLIŞKININ İNCELENMESI
}

\section{EXAMINING THE RELATIONSHIP BETWEEN PARENTAL ATTITUDES AND PERCEPTION OF SELF-CONCEPT IN PRE-SCHOOL CHILDREN}

\author{
Fatma Betül ŞENOL ${ }^{1} \quad$ Nezahat Hamiden KARACA ${ }^{2}$
}

\begin{abstract}
Başvuru Tarihi: 19-08-2019 Yayına Kabul Tarihi: 27-01-2020 $\quad$ DOI: 10.21764/maeuefd.606614 (Araştırma Makalesi)

Özet: Bu çalışmanın amacı, okul öncesi dönemdeki Abstract: The aim of this study is to examine the çocukların benlik kavramları ile ebeveyn tutumları arasındaki ilişkinin incelenmesidir. Araştırmada genel tarama modellerinden ilişkisel tarama modeli kullanılmıştır. Araştırmanın çalışma grubuna, 20182019 eğitim-öğretim yllında Afyonkarahisar İl Merkezindeki İl Milli Eğitim Müdürlüğüne bağlı okul öncesi eğitim kurumları arasından basit rastgele örnekleme yöntemi ile seçilen 48-72 ay arasında olan 201 okul öncesi dönem çocuğu ve ebeveynleri dâhil edilmiştir. Araştırmada veri toplama amacıyla, "Genel Bilgi Formu", Villa ve Auzmendi (1992) tarafindan geliştirilen ve Karaca ve Aral (2017) tarafından Türkçeye uyarlanan "Çocuğun Benlik Kavramını Algılaması (Perception of Child Self-Concept-PCSC) Ölçme Aracı" ve Karabulut Demir ve Şendil (2008) tarafından geliştirilen "Ebeveyn Tutum Ölçeği (ETÖ)" kullanılmıştır. Verilerin analizinde Çoklu Doğrusal Regresyon Analizinden yararlanılmıştır. Araştırmanın sonuçlarına göre, benlik kavramı ölçeği puanlarınnın; ebeveyn tutum ölçeği alt boyutlarından demokratik tutum alt boyutu puanlarını anlamlı ve pozitif yönlü yordadı̆̆ anlamlı ve negatif yönlü yordadığı görülmektedir. Diğer alt boyutların ise benlik üzerindeki yordayıcılığının anlamlı düzeyde olmadığı saptanmıştır. Bu sonuçlara göre demokratik ebeveyn

relationship between parental attitudes and the perception of self-concept of preschool children. The correlational survey model, which is one of the general survey models, was used in this study. The study group included 201 preschool children and their parents who were selected via simple random sampling method from pre-school education institutions functioning under the Provincial Directorate of National Education in Afyonkarahisar city center in the 2018-2019 academic year. "General Information Form", "Perception of Child SelfConcept-PCSC" that was developed by Villa and Auzmendi (1992), and "Parental Attitude Scale (PAS)" that was developed by Karabulut, Demir, and Şendil (2008) were used as the data collection tools. In the analysis of the data, the Multilinear Regression Analysis was used. According to the results,, selfconcept scale scores significantly and positively predicted the democratic attitude sub-dimension scores that was one of the parental attitude scale subdimensions, and it significantly and negatively predicted the overprotective attitude sub-dimension scores. It was determined that other sub-dimensions did not predict the self-concept at significant levels. Results indicate that parental attitudes are quite effective on the self-concept of children.
\end{abstract} tutumunun çocukların benlik kavramları üzerinde pozitif yönde, aşırı koruyucu ebeveyn tutumunun ise negatif yönde etkili olduğu söylenebilir.

Key Words: Self-concept, parental attitudes, preschool children

Anahtar Sözcükler: Benlik kavramı, ebeveyn tutumu, okul öncesi dönemdeki çocuklar

\section{Giriş}

Bireylerin yaşadıkları topluma uyum sağlamalarında kendilerini nasıl algıladıkları oldukça önemlidir. Bireylerin kendilerini algılama biçimleri benlik kavramının gelişiminde etkili olmaktadır (Miell ve Ding, 2005). Benlik kavramı, kendilik teorisi olarak adlandırılmakta;

\footnotetext{
${ }^{1}$ Araş. Gör. Dr., Afyon Kocatepe Üniversitesi Eğitim Fakültesi Temel Eğitim Bölümü Okul Öncesi Eğitimi ABD, Afyonkarahisar. E-mail: fbetululu@ aku.edu.tr, ORCID: 0000-0002-4844-4968

${ }^{2}$ Dr. Öğrt. Üyesi, Afyon Kocatepe Üniversitesi Eğitim Fakültesi Temel Eğitim Bölümü Okul Öncesi Eğitimi ABD, Afyonkarahisar. E-mail: nhamiden@ gmail.com, ORCID: 0000-0002-7424-7669
} 
bireylerin etnik ve cinsel kimlikleri de dahil olmak üzere kendi yapabildiklerini ve yeterliliklerini fark etmesi olarak tanımlanmaktadır (Butler ve Gasson, 2005; Trawick Smith, 2013). Benlik kavramı bebeklik döneminden itibaren şekillenmektedir. Süreç içerisinde çocukların edindikleri deneyimlerle sürekli gelişmekte, değişmekte ve netleşmekte, bunun sonucunda da çocuklar olumlu ve olumsuz benlik kavramına sahip olmaktadırlar (Trawick Smith, 2013).

Çocuklar dünyaya geldikleri andan itibaren olumlu benlik kavramında sahiptir. Örneğin, dört yaşındaki çocuklar bir işte başarısız olduklarında diğer denemelerinde başarılı olabileceklerini düşünmektedirler (Stipek ve Green, 2001). Bu örnekte erken yaşlarda çocukların kendilerine olan algılarının ve kendilerini değerlendirmelerinin oldukça iyimser olduğu görülmektedir. Ancak çocukların çevrelerinden aldıkları uyaranlar, tepkiler ve tutumlar ile benlik kavramlarında değişim olmaktadır. Çocukların benlik kavramı hem içsel (kendilerini algılamaları) hem de dişsal (ebeveyn, öğretmen vb.) uyaranlardan beslenmektedir (Bong ve Skaalvik, 2003; Woolfolk, 1998). Argyle (2008) benlik kavramının bireylerin tepkisi, kendimizi karşılaştırdığımız bireyler, sosyal roller, kimlik, kişilik gibi faktörlerden etkilendiğini belirtmiştir. Mcleod (2008) ise çocukların benlik kavramı üzerinde ebeveynlerin büyük etkisinin olduğunu vurgulamaktadır. Çocuklar anasınıfına başladıktan sonra çevreleri artmakta, sosyal alanları önemli ölçüde genişlemektedir. $\mathrm{Bu}$ yıllarda çocukların benlik kavramlarını öğretmen ve arkadaş gibi faktörler etkilese de ebeveynlerinin tutumları çocukların benlik kavramlarının ilerlemesinde etkili olmaya devam etmektedir (Leflot, vanLier, Verschueren, Onghena veColpin, 2011; Verschuerena , SarahDoumena ve Buyse, 2012). Çocuklar, genellikle, dünyaya geldikleri andan itibaren aileleri ile beraberdir. $\mathrm{Bu}$ durum ebeveynler ve çocuklar arasında olumlu ilişki olmasına olanak sağlayabilir (Pianta, Hamre veStuhlman, 2003; Verschueren, Marcoen ve Schoefs, 1996). Yapılan araştırmalar, ailelerinin tepkilerinin, çocukların aileleri ile olan ilişkilerinin (Berlin, Cassidy ve Appleyard, 2008; Howes ve Spieker, 2008), ailelerinin tavır ve tutumlarının olumlu olması çocukların benlik kavramları üzerinde olumlu yönde etkili olduğunu göstermektedir (Cevher ve Buluş, 2006). Bu nedenle çocukların benlik kavramı kazanımının olumlu yönde ilerlemesi için ebeveyn tutumu üzerinde durulmalıdır.

Aile, çocukların sosyal deneyimlerini ilk edindikleri sistem olarak karşımıza çıkmaktadır. Aile, sürekli bireylerin birbirleri ile etkileşim içerisinde olduğu, çocuğu hem etkileyen hem de çocuktan etkilenen bir yapıdadır. Ebeveynlerin çocuklarına yönelik tutumlarının olumlu olması, çocukların gelişimlerini olumlu yönde etkileyip sağlıklı bireyler olarak yetişmelerine 
olanak sağlamaktadır. Ebeveyn tutumu anne babaların çocuklarına nasıl yaklaştıklarını, yaşanan olaylar karşısında nasıl tepki verdiklerini ifade etmektedir (Satir, 2016; Eroğlu ve Parlar, 2018).Özyürek ve Temel Şahin (2005)'e göre ebeveynlerin çocuklarına yönelik tutumları, kendi istedikleri özellikte çocukların yetişmesi bakımından önemli bir role sahiptir. Çocukların toplum içerisinde kendilerini ifade edebilen, yetkin bireyler olmaları isteniyorsa ebeveynlerin anlayışlı, demokratik ve esnek tutum içerisinde olmaları gerekmektedir. Bu yaklaşımların aksine, aşırı baskıcı, aşırı hoşgörülü, duyarsız tutum içerisinde olan ebeveynler ise çocuklarının tutarsız ve başarısız bireyler olmasına neden olduğu söylenebilir. (Yavuzer,2001; Nelsen, Lott ve Glenn, 2002).Alanyazında ebeveyn tutumları çok çeşitli kategorilerde incelenmektedir. Bu çalışmada demokratik, aşırı koruyucu, otoriter ve izin verici ebeveyn tutumları üzerinde durulmuştur.

Demokratik ebeveyn tutumunda güven verici ve destekleyici bir ortam bulunmaktadır. Demokratik tutuma sahip ebeveynler çocuklarıyla iletişim kurmakta, çocuklarının görüş ve düşüncelerini ifade etmesine firsat vermektedirler. Aile içinde kurallar, sınırlar bulunmaktadır (Göknar, 2012). Çocuğa karşı saygılı davranılmaktadır. Kurallara tüm aile bireyleri uymaktadır. Demokratik ebeveyne sahip ailelerin çocukları kendilerini rahat ifade edebilen, özgüveni, özsaygısı gelişmiş ve en önemlisi kendi benliğini tanıma fırsatı tanınmış çocuklar olmaktadir (Gordon, 2014; Mackenzie, 2014). Otoriter ebeveyn tutumunda, ebeveynler baskııı bir şekilde çocuklarının davranışlarını denetlemeye ve kendi istekleri doğrultusunda yönlendirmeye çalışmaktadırlar. Her kararı ebeveynler vermekte, çocukların görüşleri alınmamakta, çocuklara saygılı davranılmamaktadır (Mackenzie, 2014; Yavuzer, 2016). Böyle ebeveyn tutumu içerisinde yetişen çocuklar çekingen, özgüvenleri düşük, kendi başlarına hareket edemeyen, kendisini tanımayan, uyum sorunu yaşayan çocuklar olduğu söylenebilir(Çağdaş, 2008; Santrock, 1997 Akt.Erkan, 2010). Aşırı koruyucu ebeveyn tutumunda ise ebeveynler çocuklarına zarar geleceğini düşünerek aşırı derecede koruyucu davranmaktadırlar. Bu tutuma sahip ebeveynler çocuklarını sürekli kısıtlamakta, çocukları adına karar almakta ve çocuklarının tüm ihtiyaçlarını karşılamaktadırlar (Eroğlu ve Parlar, 2018; Özyürek ve Tezel Şahin, 2012). Bu ortam çocuğun başkalarına bağımlı, tek başına hareket edemeyen, özgüveni düşük bir birey olarak yetişmesine neden olduğu söylenebilir. İzin verici ebeveyn tutumunda çocuklar ebeveynlerini kontrol etmekte, ebeveynler aşırı hoşgörülü davranmakta; aile içinde kurallar ve sınırlar belirlenmemektedir. Çocuklar uyum sağlamada zorlanmakta, doğru ile yanlışı ayırt etmekte ve sosyal ilişkilerde başarısız olabilmektedirler (Semerci, 2015; Nelsen, Lott ve Glenn, 2002; Demir ve Yavuzer, 2016). 
Yukarıdaki açıklamalar doğrultusunda, ebeveynlerin çocuklarına olan yaklaşımlarının ve tutumlarının, çocuklarının gelişimlerini önemli derecede etkilediği değerlendirilmektedir. Ebeveyn tutumunda sınırların iyi korunması ve herşeyin dengesinin olması gerektiği söylenebilir. Ebeveynler olumlu tutum içerisinde olduklarında çocukların kendilerini daha iyi algıladığı, yapabildiklerini ve yeterliklerini daha iyi fark edebildiği ve düşüncelerini daha rahat ifade edebildiği başka bir anlatımla, benlik kavramının olumlu etkilendiği düşünülebilir. Olumlu benlik kavramına sahip çocuklar kendileri ile ilgili sağlıklı görüşlerde bulunmakta, kendilerini daima mutlu ve huzurlu hissetmekte, yaşantılarından tatmin olmaktadırlar. Kendi davranışlarının sorumluluklarını almakta, duygularını kontrol edebilmektedirler. Kendilerine gerçekçi hedefler belirlemekte ve hedeflerine ulaşmak için çaba göstermektedirler. Ayrıca olumlu benlik kavramına sahip çocuklar yeteneklerinin farkına varmakta ve karşılaştıkları problemlerle kolayca baş edebilmektedirler. En önemlisi kendileriyle gurur duyduklarını göstermektedirler (Herbert ve Stipek, 2005; Tracy ve Robins, 2007; Yörükoğlu, 2007). Olumsuz benlik kavramına sahip çocuklar ise bir işe başlamaktan korkmakta, sorumluluk almaktan kaçınmakta, kendilerine yapabileceklerinin altında hedefler koymaktadırlar. Olumsuz benlik kavramına sahip olan çocukların özgüvenlerinin düşük olduğu, her şeye olumsuz bakış açısı ile yaklaştıkları ve olumsuz düşüncüleri olduğu belirtilmektedir (Yavuzer, 2018; Kutlu ve Kaya, 2004; Özçiçek, 2014). Bu açıklamalarda görüldüğü üzere, benlik kavramının düzeyi çocukların yaşamlarının tüm aşamalarını oldukça etkilemektedir. Buradan hareketle çalışmada okul öncesi dönemdeki çocukların benlik kavramları ile ebeveyn tutumları arasındaki ilişkinin incelenmesi amaçlanmıştır.

\section{Yöntem}

\section{Araştırmanın Modeli}

Araştırmada, okul öncesi çocuklarının benlik kavramı ile ebeveyn tutumları arasındaki ilişkiyi incelemek için genel tarama modellerinden ilişkisel tarama modeli kullanılmıştır. Genel tarama modelinin bir türü olan ilişkisel tarama modeli, iki ya da daha çok sayıdaki değişken arasında birlikte değişim varlığını ve/veya derecesini incelemek, neden-sonuç ile ilgili ipuçları elde etmek ve incelenen olguları daha iyi anlayabilmek amacıyla kullanılan araştırma modelidir (Karasar, 2013).

\section{Çalışma Grubu}

Araştırmanın çalışma grubuna, 2018-2019 eğitim-öğretim yılında Afyonkarahisar İl Merkezindeki İl Milli Eğitim Müdürlüğüne bağlı okul öncesi eğitim kurumları arasından basit 
rastgele örnekleme yöntemi ile seçilen okullara devam eden, gönüllülük ilkesi esas alınarak belirlenen 48-72 ay arasında olan 201 okul öncesi dönem çocuğu ve ebeveynleri dâhil edilmiştir.

Tablo 1

Okul Öncesi Dönemdeki Çocukların ve Ebeveynlerine Ait Demografik Özellikler

\begin{tabular}{|c|c|c|c|}
\hline Demografik Özellikler & Değişkenler & Frekans & Yüzde \\
\hline \multirow[t]{2}{*}{ Çocukların doğum tarihleri (ay) } & $48-60$ ay & 26 & 12,9 \\
\hline & 61 ay ve üstü & 175 & 87,1 \\
\hline \multirow[t]{2}{*}{ Cinsiyetleri } & $\mathrm{K} 1 \mathrm{z}$ & 101 & 50,2 \\
\hline & Erkek & 100 & 49,8 \\
\hline \multirow{3}{*}{ Doğum sırası } & İlk çocuk & 92 & 45,8 \\
\hline & $\begin{array}{l}\text { Ortanca veya } \\
\text { ortancalardan biri }\end{array}$ & 51 & 25,4 \\
\hline & Son çocuk & 58 & 28,9 \\
\hline \multirow[t]{2}{*}{ Ailedeki çocuk sayısı } & Bir çocuk & 42 & 20,9 \\
\hline & Birden fazla çocuk & 159 & 79,1 \\
\hline \multirow[t]{3}{*}{ Anne yaş } & 29 yaş ve altı & 48 & 23,9 \\
\hline & 30-39 yaş arası & 137 & 68,1 \\
\hline & 40 ve üstü yaşta & 16 & 8 \\
\hline \multirow[t]{3}{*}{ Baba yaş } & 29 yaş ve altı & 18 & 9 \\
\hline & 30-39 yaş arası & 143 & 71,1 \\
\hline & 40 ve üstü yaşta & 40 & 19,9 \\
\hline \multirow[t]{3}{*}{ Anne öğrenim durumu } & İlk ve orta okul & 37 & 18,4 \\
\hline & Lise & 83 & 41,3 \\
\hline & Üniversite & 81 & 40,3 \\
\hline \multirow[t]{3}{*}{ Baba öğrenim durumu } & İlk ve orta okul & 24 & 11,9 \\
\hline & Lise & 53 & 26,4 \\
\hline & Üniversite & 124 & 61,7 \\
\hline \multirow[t]{2}{*}{ Anne çalışma durumu } & Çalışıyor & 99 & 49,3 \\
\hline & Çalışmıyor & 102 & 50,7 \\
\hline \multirow[t]{2}{*}{ Baba çalışma durumu } & Çalışıyor & 195 & 97 \\
\hline & Çalışmiyor & 6 & 3 \\
\hline
\end{tabular}

Çalışma grubuna dahil edilen okul öncesi dönem çocuklarının demografik özellikleri incelendiğinde; \%12,9'unun 48-60 ay arasında olduğu, \%87,1'inin 61 ve üstü ay arasında olduğu,\%50,2'sinin kız olduğu, \%49,8'inin erkek olduğu, \%45,8'inin ilk çocuk,\%25,4'ünün ortanca veya ortancalardan biri olduğu, $\% 28,8$ 'inin son çocuk olduğu belirlenmiştir. Ayrıca ebeveynlerin demografik özellikleri incelendiğinde; \%20,9'unun bir çocuk sahibi oldukları, \%79,1'inin birden fazla çocuğa sahip oldukları, annelerin;\%23,9'unun 29 yaş ve altında oldukları, \%68,1'inin 30-39 yaş arasında olduğu, \%8'inin 40 ve üstü yaşta olduğu, \%18,4'ünün ilk ve ortaokul mezunu olduğu, \%41,3'ünün lise mezunu olduğu, \%40,3'ünün üniversite mezunu olduğu, \%50,7'sinin çalışmadığ1, \%49,3'ünün çalıştığ1 saptanmıştır. 
Babaların ise;\%9'unun 29 yaş ve altında oldukları, \%71,1'inin 30-39 yaş arasında olduğu, \%19,9'unun 40 ve üstü yaşta olduğu, \%11,9'unun ilk ve ortaokul mezunu olduğu, \%26,4'ünün lise mezunu olduğu, \%61,7'sinin üniversite mezunu olduğu, \%3'ünün çalışmadığ,$\% 97$ 'sinin çalıştığı saptanmıştır

\section{Veri Toplama Araçları}

Araştırmada veri toplama amacıyla, "Genel Bilgi Formu”,"Çocuğun Benlik Kavramını Algılaması (Perception of Child Self-Concept-PCSC) Ölçme Aracı" ve "Ebeveyn Tutum Ölçeği (ETÖ)’’kullanılmıştır.

Genel bilgi formu.Araştırmacılar tarafından oluşturulan formda; çocuğun cinsiyeti, yaşı, kardeş sayısı, doğum sırası,anne-baba yaşı, anne-baba öğrenim durumu,anne-baba mesleğini belirlemeye yönelik sorular yer almaktadır.

Çocuğun benlik kavramını algılaması (Perception of child self-concept-PCSC). Benlik Kavramını Algılama ölçme aracı Villa ve Auzmendi (1992) tarafından beş- altı yaş çocuklarının benlik kavramının değerlendirilmesi amacı ile geliştirilmiştir. Karaca ve Aral (2017) tarafından Türkçeye uyarlama çalışması yapılmıştır. Bu ölçme aracı, olumlu ya da olumsuz benlik kavramına sahip olan çocukları basitçe ve ekonomik olarak tanımlamada kullanılmaktadır. Ölçme aracı otuz dört maddeden ve her maddeye ait olan otuz dört resimden oluşmakta ve uygulama her çocuk için 15-20 dakika sürmektedir. Çocuğun Benlik Kavramını Algılama ölçme aracına ait geçerlik ve güvenirlik analizleri; anaokullarına devam eden, normal gelişim gösteren 170 çocuk ile yapılmıştır. Ölçme aracı bir ile dört arasında puanlanmakta, 1 en düşük 4 ise en yüksek benlik kavramını temsil etmektedir. Ancak 13. maddede ters puanlama söz konusu olup, 1 puan 4, 4 puan ise 1 olarak değerlendirilmektedir. Çocuğun Benlik Kavramını Algılaması ölçme aracında yer alan uygulama yönergesinin ve değerlendirme ölçütlerinin kapsam geçerliği ve Türk kültürüne uygunluğu için uzman görüşüne başvurulmuştur. Uzman görüşleri sonucunda kapsam geçerliği indeksi (KGI) 0,93 olarak belirlenmiştir. Çocuğun Benlik Kavramını Algılaması değerlendirme ölçütlerine ilişkin ( $n=170)$ madde toplam korelasyonu ve Cronbach alfa analizi sonuçlarına göre, güvenirlik katsayısı testin tümü için .69 ve madde toplam korelasyonlarının çoğunluğunun yeterli düzeyde olduğu bulunmuştur. Çocuğun Benlik Kavramını Algılaması ölçme aracının puanlarına göre oluşturulan üst \%27 ve alt \%27'lik grupların ortalama puanları arasındaki farkın $(t=-19, p<.01)$ anlamlı çıkması, Çocuğun Benlik Kavramını Algılaması ölçme aracının maddelerinin benlik kavramının değerlendirilmesinde ayırt edici olduğu sonucunu ortaya çıkarmıştır. Çocuğun Benlik Kavramını Algılaması ölçme aracının test-tekrar test güvenirlik 
katsayıları $(n=40)$ iki test sonuçları arasındaki ilişkinin pozitif, yüksek düzeyde ve anlamlı olduğu, buna göre, ölçme aracının zamana bağlı olarak kararlı bir yapı gösterdiği belirlenmiştir (Karaca ve Aral, 2017).

Ebeveyn tutum ölçeği (ETÖ): Karabulut Demir ve Şendil (2008) tarafindan ebeveynlerin 2-6 yaş arasındaki çocuklarına olan davranışlarını ölçmek amacıyla geliştirilmiştir. Boyutlar: Demokratik Tutum, Otoriter Tutum, Aşırı Koruyucu Tutum, İzin Verici Tutum olmak üzere dört alt boyuttan ve kırk altı maddeden oluşmaktadır. Hazırlanan ölçek Likert tipi bir ölçme aracıdır. Oluşturulan maddeler davranış biçimleri şeklindedir ve her bir davranış biçiminin karşısında cevaplayıcıların seçecekleri, sıklık oranlarına göre farklılaşan 5 seçenek bulunmaktadır. Her madde için bu seçeneklerden biri işaretlenmektedir. Puanlama "Her zaman böyledir" 5 puan; "Çoğunlukla böyledir" 4 puan; "Bazen böyledir" 3 puan; "Nadiren böyledir" 2 puan ve "Hiçbir zaman böyle değildir"1 puan şeklinde yapılmaktadır. Her boyuttan alınan puanlar ayrı ayrı hesaplanarak her boyut için bir puan elde edilmektedir. Bir boyuttan yüksek puan almak o boyutun temsil ettiği davranış şeklini benimsemek anlamına gelmektedir. ETÖ boyutlarının güvenirliklerini tespit etmek üzere iç tutarlık katsayıları incelenmiştir. Boyutların Cronbach alfa güvenirlik katsayıları demokratik boyut için .83 , otoriter boyut için .76 , aşırı koruyucu boyut için .75 ve izin verici boyutu için .74’tür. ETÖ’nün geçerliğini sınamak üzere ilk olarak faktör analizi kullanılmıştır. Yapılan factor analizi bulguları ile .30'un altında kalan ve birden fazla faktöre yüklenen ya da hiçbir faktöre yüklenmeyen 16 madde ölçekten çıkarılmıştır. Factor analizi sonucunda ölçek 46 madde ve dört boyuttan oluşmuştur.

\section{Verilerin Analizi}

Araştırmada, 48- 72 ay arasında olan 201 çocuğa ve ebeveynlerine ait demografik özelliklerin değerlendirilmesinde frekans ve yüzde gibi betimsel istatistikler kullanılmıştır. Verilerin doğrusallık, normal dağılım ve varyansların homojenliğine bakılmıştır. Kolmogorov-Smirnov testi ile analiz edilerek verilerin normal dağılım gösterdiği tespit edilmiştir. Doğrusallık varsayımını kontrol etmek için "standardize edilmiş artık-yordanan değerler" ile bağımlı ve bağımsız sürekli değişkenlerin saçılım grafiği incelenmiş ve doğrusal ilişkinin varlığı gözlemlenmiştir. Aynı zamanda verilerin homojen dağıldığı belirlenmiştir. Çocuğun Benlik Kavramını Algılaması ile Ebeveyn Tutum Ölçeği'nden elde edilen verilerin analizinde bağımlı değişkeni (benlik kavramı) bağımsız değişkenlerin (ebeveyn tutumları) yordayıp yordamadığını belirleyebilmek için Çoklu Doğrusal Regresyon Analizi 
kullanılmıştır. Çoklu Doğrusal Regresyon analizi, bir bağımlı ve birden çok bağımsız değişkenin olduğu analiz türüdür (Alpar,2018).

\section{Bulgular}

$\mathrm{Bu}$ çalışmada, okul öncesi çocuklarının benlik kavramı ile ebeveyn tutumları arasındaki ilişkiyi incelemek amacıyla yapılan araştırmanın sonuçları aşağıda sunulmuştur.

Tablo 1

Okul Öncesi Dönemdeki Çocukların Benlik Kavramlarının Ebeveyn Tutumlarını Yordama Düzeyine İlişkin Çoklu Regresyon Analizi Sonuçları

\begin{tabular}{lcccccccc}
\hline \multicolumn{1}{c}{ Benlik Kavramı } & $\mathrm{R}$ & $\mathrm{R}^{2}$ & $\mathrm{~F}$ & $\mathrm{~s} / \mathrm{d}$ & $\mathrm{B}$ & $\beta$ & $\mathrm{t}$ & $\mathrm{p}$ \\
\hline Sabit & .250 & .062 & 3.263 & $4 / 196$ & 3.285 & - & 19.233 & $.000^{*}$ \\
Demokratik Tutum & & & & & .093 & .244 & 2.813 & .005 \\
Otoriter Tutum & & & & & .035 & .102 & 1.077 & .283 \\
Assirı Koruyucu & & & & & -.054 & -.174 & -2.381 & .018 \\
Tutum & & & & & .026 & .086 & 1.061 & .290 \\
İzin Verici Tutum & & & & .026 \\
\hline
\end{tabular}

Tablo 1 incelendiğinde okul öncesi çocukların benlik puanlarındaki değişimin ebeveyn tutum ölçeği alt boyutları(Demokratik Tutum, Otoriter Tutum, Aşırı Koruyucu Tutum ve İzin Verici Tutum) puanlarındaki değişimin ancak .06'sını yordadığı belirlenmiştir. Çoklu regresyon sonuçları ebeveyn tutum ölçeği alt boyutları ile benlik ölçeği arasında anlamlı bir ilişki olduğunu göstermektedir $\left(\mathrm{R}=.250, \mathrm{R}^{2}=.062, \mathrm{p}<.05\right)$. Bu oran çok yüksek olmamakla beraber benlik kavramı ölçeği puanlarında; ebeveyn tutum ölçeği alt boyutlarından demokratik tutum alt boyutu puanlarını anlamlı ve pozitif yönlü yordadığı, aşırı koruyucu tutum alt boyutu puanlarını anlamlı ve negatif yönlü yordadığı görülmektedir. Diğer alt boyutların ise benlik üzerindeki yordayıcılığının anlamlı düzeyde olmadığı saptanmıştır.

\section{Tartışma ve Sonuç}

Çocukların çevreleriyle etkileşim kurmaları yaşamlarında oldukça önemlidir. Çocukların ilk ve en fazla etkileşim kurduğu kişiler doğdukları andan itibaren beraber oldukları ebeveynleridir. Yaşamını ebeveynleri ile kurduğu ilişki ağı ile geçiren çocukların mutlu, kendine güvenen, benlik kavramı gelişmiş bireyler olarak yetişmesinde, ebeveynlerin çocuklarına karşı tutum ve davranışlarının rolü büyüktür (Huang ve Larry Prochner, 2003; Hoghughi ve Long, 2004). Bu çalışma, okul öncesi dönemdeki çocukların benlik kavramları 
ile ebeveyn tutumları arasındaki ilişkiyi incelemek amacıyla yapılmıştır. Çalışmanın sonucunda demokratik tutuma sahip ebeveynlerin çocuklarının benlik kavramlarını pozitif yönlü; aşırı koruyucu tutuma sahip ebeveynlerin çocuklarının benlik kavramlarını negatif yönlü yordadığı görülmektedir. Başka bir deyişle, demokratik tutuma sahip ebeveynlerin çocuklarının benlik kavramları yüksek; aşırı koruyucu tutuma sahip ebeveynlerin çocuklarının benlik kavramları düşük olduğu söylenebilir. Alan yazın incelendiğinde çalışmadan elde edilen sonuçları destekleyen araştırmalar olduğu görülmektedir.

Brown ve Ryan'a göre (2003) ebeveynlerin tutumlarının olumlu benlik kavramına sahip çocuklar yetişmesinde önemli bir rolü bulunmakta ve çocukların benlik kavramları ile ebeveyn tutumları arasında pozitif yönlü ilişki bulunmaktadır. Pesu, Viljaranta ve Aunola (2016) 6-8 yaş arasındaki çocuklar ve ebeveynleri ile yaptıkları çalışmada, ebeveynlerin çocuklarına yönelik olumlu inançlarının olmasının çocukları ile olumlu ilişkiler kurmasını ve çocukların benlik kavramını olumlu yönde etkilediğini belirtmiştir. Skowron (2005) okul öncesi dönem çocukların benlik kavramları ile ebeveyn tutumlarını incelediği araştırma bulgularına göre, olumsuz ebeveyn tutumuna sahip olan annelerin çocuklarının benlik kavramlarının olumlu tutuma sahip ebeveynlerin çocuklarından daha düşük olduğu sonucuna ulaşmıştır. Ayrıca okul öncesi dönemdeki çocukların ebeveynlerinin çocuklarına karşı olumlu davranış göstermeleri durumunda akademik benlik kavramlarının yükseldiği bulunmuştur (Altınok, 2017; Sangawi, Adams ve Reissland, 2016). Okul öncesi dönemdeki çocuklar ve aileleri ile yapılan çalışmaların yanısıra ergenler ve gençlerle yapılmış ve benzer sonuçlara ulaşılmış çalışmalar bulunmaktadır. Herz ve Gullone'nin (1999) ve Lamborn, Mounts, Sreinberg ve Darnbusch'ın (1991) yaptıkları çalışmalarda hoşgörülü ebeveyn tutumuna sahip ortamlarda yetişen ergenlik dönemindeki çocukların benlik kavramlarının, baskıcı ve otoriter ebeveyn tutumuna sahip ortamlarda yetişen çocuklara göre daha olumlu olduğu sonucuna ulaşılmıştır. DeHart, Pelham ve Tennen (2006) yaş ortalaması 19 olan genç yetişkin çocukların ebeveyn tutumları ile benlik kavramını inceledikleri çalışmanın sonucunda hoşgörülü ve demokratik tutuma sahip ebeveynlerin çocuklarının benlik kavramları, baskıcı ve otoriter tutuma sahip ebeveynlerin çocuklarına göre daha yüksek olduğunu belirtmişlerdir. Ryan ve Brown (2005) de aşırı koruyucu, baskıcı ve otoriter tutuma sahip ebeveynlerin çocuklarının zayıf benlik kavramına sahip oldukları üzerinde durmuştur. Haktanır ve Baran (1998) gençlerin benlik kavramları ile anne baba tutumlarını incelediği çalışmanın sonucunda demokratik ebeveyn tutumunun yüksek özsaygıya, otoriter ve ilgisiz ebeveyn tutumunun ise düşük özsaygıya neden olduğu sonucuna ulamışlardır. Adana ve Kutlu (2009) ise benzer 
şekilde, ergenlerin benlik kavramları ve ebeveyn tutumlarının pozitif yönde ilişkili olduğunu belirtmişlerdir.

Demokratik tutuma sahip ebeveynlerin bulunduğu aile ortamı güven verici ve destekleyicidir. Demokratik ortamda yetişen çocukların aileleri ile ilişskileri olumludur ve çocuklar olumlu benlik kavramına sahiptir (Gordon, 2014; Mackenzie, 2014). Ek olarak benlik kavramı yüksek olan çocukların özgüvenlerinin de yüksek olduğu söylenebilir (Günap ve Kabadayı, 2017; Kasatura, 1998). Bu doğrultuda Günap ve Kabadayı'nın (2017) okul öncesi dönem çocukları ile yaptıkları çalışmanın sonucunda, demokratik tutuma sahip anne babaların çocukların özgüvenleri üzerinde anlamlı ve pozitif yönde etkisi olduğu vurgulanmıştır. Dekovich ve Meeus (1997) yaptığı çalışmada ebeveynleri ile olumlu ilişkiye sahip olan ergenlerin benlik kavramlarının olumlu olduğu sonucuna ulaşmıştır.

Benlik kavramı, ebeveynlerin çocuklarına yansıttıkları farklı tavırlardan da etkilenir. Bunların biri mükemmeliyetçilik kavramıdır. Mükemmeliyetçi ebeveynler kusursuz çocuk istedikleri için çocuklarının üzerinde baskı kurarlar. Bir nevi otoriter ve baskıcı tutum içerisinde olurlar. Böylece çocukların benlik kavramları üzerinde olumsuz etkide bulunurlar (Flett ve Hewitt, 2002; Flett, Davis ve Hewitt, 2003). Özçiçek (2014) annenin mükemmeliyetçiliği ile çocuğunun benlik kavramı arasındaki ilişkiyi incelemek amacıyla yaptığı çalışmanın sonucunda annelerin mükemmeliyetçi yapısının çocukların benlik kavramlarını negatif yönlü yordadığı sonucuna ulaşmıştır. Günap ve Kabadayı (2017) baskıcı ve otoriter tutuma sahip ebeveynlerin 5-6 yaş çocuklarının özgüvenlerini olumsuz yönde etkilediği sonucuna ulaşmıştır.

Aşırı koruyucu tutuma sahip ebeveynler çocukları üzerinde aşırı kontrolcü bir yapıya sahip olup, çocuklarının kendilerini algılayıp tanıyabileceği alan bırakmazlar (Eroğlu ve Parlar, 2018). Böyle ortamda yetişen çocukların özgüvenlerinin ve benlik kavramlarının düşük olacağı değerlendirilebilir. Annelerin çocuklarına özerklik tanımaması, sürekli eleştirmesi ve tüm davranışlarına karşı koruyucu tutum içerisinde bulunması ebeveynlerin kaygı düzeyi ile de ilişkilendirilmektedir (Can, 2015). Yapılan bir çalışmada, ebeveynlerin kaygı düzeylerinin yükselmesinin okul öncesi dönemdeki çocukların benlik kavramlarını olumsuz yönde etkilediği sonucuna ulaşılmıştır (Demirci, 2018). 5-6 yaş çocukları ile yapılan çalışmanın sonucunda, aşırı koruyucu tutuma sahip ebeveynlerin çocuklarının özgüvenlerinin olumsuz yönde etkilendiği belirtilmiştir (Günap ve Kabadayı, 2017). Abd-El-Fattah ve Fakrooh'un (2012) babaların psikolojik kontrolcü yapısı ile ergenlerin benlik saygısı ve 
mükemmeliyetçilik yapısını incelediği çalışmanın sonucunda mükemmeliyetçilik ile benlik saygısı arasında negatif yönlü ilişki olduğunu belirtmiştir.

İzin verici ebeveyn tutumunda ebeveynler çocukları ile çok samimi ve onlara karşı aşırı hoşgörülüdürler. Böyle bir ebeveyn ortamında çocukların kendilerini algılamaları değerlendirmeleri için ebeveyn desteğinin olmadığı ve benlik kavramının olumsuz yönde etkilendiği ve çocuklarda problem davranışlara neden olabileceği söylenebilir (Papalia ve Feldman, 2011). Bu konuda yapılan araştırmalar incelendiğinde, izin verici tutuma sahip ebeveynlerin çocuklarının benlik kavramı gelişimleri ile ilgili çalışmaya rastlanmamıştır. $\mathrm{Bu}$ nedenle izin verici tutuma sahip ebeveynlerin çocuklarının sosyal davranışları ve problem davranışları ile ilgili çalışmalar eklenmiştir. Eisenberg ve Mussen (1989), izin verici tutuma sahip ebeveynlerin çocuklarının daha çok olumsuz sosyal davranışta bulunduğunu belirtmiştir. Çocukların olumsuz sosyal davranışta bulunmaları sosyal ortama kabullerini olumsuz etkileyerek benlik kavramları üzerinde negatif yönlü etki oluşturabilir. Avan (2018) izin verici ebeveyn tutumuna sahip ailelerin 4-6 yaş aralığındaki çocuklarının daha çok sosyal problem gösterdiği sonucuna ulaşmıştır. Ceylan (2017) okul öncesi dönemdeki çocuklar ve ebeveynleri ile yaptığı çalışmanın sonucunda, ebeveynlerin izin verici tutumları olumlu yönde geliştikçe, sosyalleşme sürecindeki uyumsuzluklarının ortadan kalkacağı sonucuna ulaşmıştır. Sosyal problemler ve olumsuz sosyal davranışlar çocukların destek aldığı, iyi niyetli güvenilir ebeveyn ortamında olumlu yöne çekilebilir. $\mathrm{Bu}$ şekilde de çocukların kendilerine yönelik değerleri ve özsaygılarında artış gözlenerek benlik kavramları olumlu yönde etkilenebilir. Ebeveyn tutumlarının çocukların benlik kavramları üzerinde etkili olduğu çeşitli gelişim kuramları ile de desteklenmektedir.

Bronfenbrenner tarafından geliştirilen Ekolojik Sistem Kuramı'na göre, çocuklar sosyal davranışları karşılıklı etkileşim içerisinde oldukları bireylerden öğrenmektedir. Kuramın mikrosistem tabakasında bulunan ebeveynler, çocukların en çok etkileşime girdiği bireyler arasında yer almaktadır. Kuramda çocuk ve ebeveynler arasındaki etkileşimin niteliği, kalitesi ve ebeveynlerin çocuklarına karşı davranışları, çocukların gelişimi üzerine etkili olduğu belirtilmektedir (Bronfenbrenner ve Morris, 2006; Miller, 2008). Bronfenbrenner'in Ekolojik Sistem Kuramı'nda ebeveynlerin tutumlarının çocukların benlik kavramları üzerinde etkili olduğu söylenebilir.

Benlik kavramı ve ebeveyn tutumları ile ilgili diğer bir kuram ise Cooley ve Mead tarafından geliştirilen Sembolik Etkileşimcilik Kuramı’dır. Çocuklar etkileşim yolu ile kendilerine ve çevresindeki insanlara anlamlar yüklemektedir. Bu şekilde benlik yapısının gelişimi 
desteklenmektedir. Kuramda, çocukların benlik gelişiminin, temel bağlanma figürleri olan ebeveynlerinin davranışlarını, yaklaşımlarını ve tutumlarını gözlemleyerek oluştuğu vurgulanmaktadır (Broderick ve Blewitt, 2010). Sembolik Etkileşimcilik Kuramı’nın doğrudan benlik gelişiminde ebeveyn davranışlarının rolünü vurgulayan açıklamaları çalışmamızın sonuçları ile ilişkili olduğu düşünülmektedir. Ebeveynler olumlu davranışa sahip olduklarında demokratik bir ev ortamı oluşturduklarında çocukların benlik kavramlarının olumlu yönde; aşırı koruyucu, otoriter, baskıcı veya izin verici tutum içerisinde olduklarında benlik kavramlarının olumsuz yönde etkileneceği söylenebilir.

Bowlby’nin Bağlanma Kuramı ise çocukların anne ve bakım veren arasında kurulan ilişkiye odaklanmaktadır. Kurama göre, aşırı hoşgörülü ve izin verici olmayarak, ebeveynin aşırıya kaçmayacak biçimde sıcak, anlayışlı, sevgi dolu, güven verici ve demokratik ebeveyn tutumu içerisinde olması, çocukların güvenli bağlanmasına ve olumlu benlik kavramının oluşmasına olanak sağlamaktadır (Broderick ve Blewitt, 2010). Ancak ebeveynlerin aşırı koruyucu, kontrolcü, baskıcı, otoriter, aşırı hoşgörülü, aşırı izin verici, tehditkar, duygusuz, tutarsız olma gibi davranışlar ve tutumlar içerisinde olması güvenli bağlanmayı zedeleyebilmektedir. $\mathrm{Bu}$ şekilde çocuklar kendileri hakkında olumsuz algılara sahip olurlar (Kesebir, Kavzoğlu ve Üstündağ, 2011; Kuyumcu, 2011). Bu açıdan bakıldığında, çalışmamızın sonuçlarının Bağlanma Kuramı ile de desteklendiğini söyleyebiliriz.

Çalışmadan ve yapılan araştırmalardan elde edilen sonuçlar ve bazı gelişim kuramları ebeveyn tutumunun çocukların benlik kavramları üzerinde oldukça belirleyici rol oynayabildiğini göstermektedir.

Çalışmadan elden edilen sonuçlar doğrultusunda aşağıdaki öneriler sunulabilir;

- Araştırma, çalışma grubuna dahil edilen 201 çocuk ve ebeveyni ile sınırlıdır. Çalışma daha yüksek sayıda çocuğa uygulanabilir.

- Ebeveynlerinin demokratik tutumlarının çocukların benlik kavramlarını olumlu yönde etkilediği sonucu doğrultusunda, ebeveynlerin tutumlarını destekleyici çalışmalara yer verilebilir.

- Ebeveynlerinin aşırı koruyucu, otoriter ve izin verici tutumlarının çocukların benlik kavramlarını olumsuz yönde etkilediği sonucu doğrultusunda, ebeveynlerin demokratik ve olumlu tutum sergileyecekleri müdahale programları uygulanabilir ve bu tutumlara sahip çocukların benlik kavramlarını geliştirecek şekilde müdahale programları uygulanabilir. 
- Ebeveyn tutumlarının çocukların benlik kavramı kazanımları üzerindeki etkisinin değişimi boylamsal çalışmalarla uzun süre takip edilebilir.

\section{Kaynakça}

Abd-El-Fattah, S. M., \& Fakrooh, H. A. (2012). The relationship among parental psychological control and adolescents' perfectionism and self-esteem: A partial least squares path analyses. Psycholoy. 3(5), 428-439.

Adana, F.,\& Kutlu, Y. (2009). Anne-baba tutumlarının adolesanların kendilik kavramı üzerine etkisi. Atatürk Üniversitesi Hemşirelik Yüksekokulu Dergisi, 12(2),18-23.

Alpar, R. (2018). Spor sağllk ve eğitim bilimlerinden örneklerle uygulamall istatistik ve geçerlik güvenirlik.(5.baskı) Ankara: Detay Yayıncılık.

Altınok, M. (2017). Annelik stilleri ile okul öncesi dönem çocuklarının sosyal duygusal uyumu ve akademik benlik sayğısı arasındaki ilişkinin belirlenmesi. (Yayınlanmamış Yüksek Lisans Tezi). Aksaray Üniversitesi, Aksaray.

Argyle, M. (2008). Social encounters: Contributions to social interaction. New York: Routledge.

Avan, N. (2017). Okul öncesi dönem 4-6 yaş grubu çocuklarda görülebilen ruhsal sorunlar ile ebeveyn tutumları arasındaki ilişsinin incelenmesi. (Yayınlanmamış Yüksek Lisans Tezi). Çağ Üniversitesi: Mersin.

Berlin, L.J.,Cassidy, J., \&Appleyard, K. (2008). The influence of early attachments on other relationships. J. Cassidy \& P.R. Shaver (Eds.), Handbook of Attachment: Theory, Research, and Clinical Applications (2nd ed.), 333-347. New York, NY: Guilford Press.

Bong, M., \& Skaalvik, E.M. (2003). Academic self-concept and self-efficacy: How different are they really? Educational Psychology Review, 15(1), 1-40.

Broderick, P. C., \& Blewitt, P. (2010). The life span human development for helping professionals. New Jersey, NJ: Pearson.

Bronfenbrenner, U., \& Morris, P.A. (2006). The bioecological model of human development. R.M. Lerner (Ed.), Theoretical Models of Human Development (6th ed.), 793-828. New York, NY: Wiley.

Brown, K.W., \& Ryan, R. M. (2003).The benefits of being present: Mindfulness and its role in psychological well-being. Journal of Personality and Social Psychology, 84, 822848.

Can, A. (2015). Okul öncesi dönemde okula gitme zorluğu yaşayan çocukların annelerinin sürekli kaygı düzeyleri ile bağlanma biçimleri arasındaki ilişkinin incelenmesi. (Yayınlanmamış Yüksek Lisans Tezi). İstanbul Arel Üniversitesi, İstanbul. 
Cevher, F. N., \& Buluş, M. (2006). Okul öncesi eğitim kurumlarına devam eden 5-6 yaş çocuklarında akademik benlik saygısı. Dokuz Eylül Üniversitesi Buca Eğitim Fakültesi Dergisi, 20, 28-39.

Ceylan, Ö. (2017). Anne baba tutumları ile çocuğun sosyalleşme süreci arasındaki ilişki: Okul öncesi örneği. (Yayınlanmamış Yüksek Lisans Tezi). İstanbul Gelişim Üniversitesi, İstanbul.

Çağdaş, A. (2008). Anne baba çocuk iletişimi. Ankara: Kök Yayıncılık.

DeHart, T.,Pelham, B. W., \& Tennen, H. (2006). What lies beneath: Parenting style and implicit self-esteem. Journal of experimental social psychology, 42(1), 1-17.

Dekovich, M., \&Meeus, W. (1997). Peer relations in adolescence: Effect of parenting and adolescents' self-concept. Journal of Adolescence, 20, 163-176.

Demir, İ. ve Yavuzer, H. (2016). Yeni kuşak anne-babalar ve çocukları. İstanbul: Remzi Kitabevi.

Demirci, E. (2018). 5-6 yaş çocuklarının annelerinin sürekli kaygı düzeyleri ile çocukların benlik algısı arasındaki ilişkinin incelenmesi. (Yayınlanmamış Yüksek Lisans Tezi) Maltepe Üniversitesi, İstanbul.

Eisenberg, N., ve Mussen, P. (1989). The roots of prosocial behavior in children. Cambridge: Cambridge University Press.

Erkan, S. (2010). Aile ve aile eğitimi ile ilgili temel kavramlar. F. Temel (Ed.). Aile Eğitimi ve Erken Çocukluk Eğitiminde Aile Katılımı, 3-43. Ankara: Anı Yayıncılık.

Eroğlu, F.,\& Parlar, H. (2018). Evli kadın ve erkeklerde psikolojik iyi oluşun ebeveyn tutumuna etkisinin incelenmesi. İstanbul Ticaret Üniversitesi Sosyal Bilimler Dergisi 17(33), 89-101.

Flett, G. L., \& Hewitt, P. L. (2002). Perfectionism and maladjustment: An overview of theoretical, definitional, and treatmentissues. G. L. Flett \& P. L. Hewitt (Eds.), Perfectionism: Theory, Research, and Treatment, 5-31. Washington, DC: American Psychological Association.

Flett, G. L., Davis, R. A., \&Hewitt, P. L. (2003). Dimendions of perfectionism, unconditional self-acceptance, and depression. Journal of Rational-Emotive ve Cognitive-Behavior Therapy, 21(2), 119-138.

Gordon, T. (2014). Etkili anne baba eğitimi. (Çev. Tekin, D. \&Özkan, N.). İstanbul: Profil Yayınları.

Göknar. Ö. (2012). Bilinçli çocuk yetiştirme. Ankara: Arkadaş Yayınları.

Günalp, A., \& Kabadayı, A. (2017). Anne-baba tutumlarının okulöncesi eğitim çağındaki çocukların özgüven duygusunun gelişimine etkisi. Journal of Human Sciences, 14(3), 2762-2776. 
Haktanır, G.,\& Baran G. (1998). A study of adolescents' self-esteem and their perceptions about parental attitudes. Turk J Child Adolesc Ment Health, 5(3), 134-141.

Herbert, J., \& Stipek, D. (2005). The emergence of gender differences in children's perceptions of academic competence. Journal of Applied Developmenral Psychology, 26, 276-295.

Herz, L., \& Gullone, E. (1999). The relationship between self-esteem and parenting style: A cross-cultural comparison of Australian and Vietnamese Australian adolescents. Journal of cross-cultural psychology, 30(6), 742-761

Howes, C., \&Spieker, S. J. (2008). Attachment relationships in the context of multiple caregivers. J. Cassidy\& P.R. Shaver (Eds.), Handbook of Attachment: Theory, Research, and Clinical Applications (2nd ed.), 317-332. New York, NY: Guilford Press.

Huang, J., \& Prochner, L. (2003) Chinese parenting styles and children's self-regulated learning. Journal of Research in Childhood Education, 18(3), 227-238.

Hoghughi, M., \&Long, N. (2004). Handbook of parenting: theory and research for practice. London: Sage Publication.

Karaca, N. H., \& Aral, N. (2017). Yaratıcı rahatlama çalışmalarının anaokuluna devam eden çocukların benlik kavramı ve motor yaratıcılığına etkisinin incelenmesi. Kuramsal Eğitimbilim Dergisi, 10(1), 146-169.

Karabulut Demir, E., \& Şendil, G. (2008). Ebeveyn tutum ölçeği (ETÖ). Türk Psikoloji Yazllarl, 11(21), 15-25.

Karasar, N. (2013). Bilimsel araştırma yöntemi (25. baskı). Ankara: Nobel Yayın Dağıtım.

Kasatura, İ. (1998). Kişilik ve özgüven. İstanbul: Evrim Yayınevi.

Kesebir S., Kavzoğlu S., \& Üstündağ M. F. (2011). Bağlanma ve psikopatoloji. Psikiyatride Güncel Yaklaşımlar-Current Approaches in Psychiatry, 3 (2), 321-342

Kutlu, M.,\& Kaya, A. (2004). Bireyi tanıma ve bireyi tanıma teknikleri. A. Kaya (Ed.), Psikolojik Danışma ve Rehberlik, 214-215. Ankara: Anı Yayıncılık.

Kuyumcu, B. (2011). Evli kişilerde gestalt temas biçimleri ve bağlanma stilleri arasındaki ilişkinin incelenmesi. Mehmet Akif Ersoy Üniversitesi Sosyal Bilimler Enstitüsü Dergisi, 5, 57-70.

Lamborn, S. D., Mounts, N., Steinberg, L., \& Dornbusch, S. (1991). Patterns of competence and adjustment among adolescents from authoritative, authoritarian, indulgent and neglectful families. Child Development, 62, 1049-1065

Leflot, G.,vanLier, P.A.C., Verschueren, K., Onghena, P., \&Colpin, H. (2011). Transactional associations among teacher support, peer social preference, and child externalizing behavior: A four-wave longitudinal study. Journal of Clinical Child and Adolescent Psychology, 40, 87-99. 
McLead, S. (2008). Self Concept. http://www.simplypsychology.org/self-concept.html Erișim Tarihi: 19.08.2019.

Mackenzie, R. J. (2014).Çocuğunuza sınır koyma. İstanbul: Yakamoz

Miell, D.,\& Ding, S. (2005). The early development of identity. S. Ding. \& K. Littlleton (Eds.), Children's Personal and Social Development, 130-140. Oxford, England: Blackwell Publishing.

Miller, P .H. (2008). Gelişim psikolojisi kuramları. Ankara: İmge Kitabevi Yayınları.

Nelsen, J.,Lott, L.,\&Glenn, S. (2002). Çocuk gelişiminde a'dan z'ye pozitif disiplin. (Çev. Ersin, M.). İstanbul: Hayat Yayıncilı.

Özçiçek, G. (2014). Çocuğun benlik kavramının olumluluğu, annenin mükemmeliyetçiliği ve anne kabul red algısı arasındaki ilişkilerin incelemesi.(Yayınlanmamış Yüksek Lisans Tezi) İstanbul Arel Üniversitesi, İstanbul.

Özyürek, A.,\& Temel Şahin, F. (2005). 5-6 yaş grubunda çocuğu olan ebeveynlerin tutumlarının incelenmesi, Gazi Ĕ̆itim Fakültesi Dergisi, 25(2), 19-34.

Papalia, D. E., \& Feldman, R. D. (2011). A child's world infancy through adolescence. Twelfth Edition, New York: Mc Graw Hill Connect Learn Succeed.

Pesu, L., Viljaranta, J., \& Aunola, K. (2016). The role of parents' and teachers' beliefs in children's self-concept development. Journal of Applied Developmental Psychology, 44, 63-71

Pianta, R.C., Hamre, B., \& Stuhlman, M. (2003). Relationships between teachers and children. W.M. Reynolds, G.E. Miller, \& I.B. Weiner (Eds.), Handbook of Psychology: Educational Psychology (Vol. 7), 199-234.Hoboken, NJ: Wiley.

Ryan, R.M., \& Brown, K.W. (2005). Legislating competence: The motivational impact of highstakes testing as an educational reform. C. Dweck\& A. E. Elliot (Eds.), Handbook of Competence, 354 374. New York: Guilford Press.

Sangawi, H., Adams, J., \& Reissland, N. (2016). The impact of parenting styles on children developmental outcome: The role of academic self-concept as a mediator. International Journal of Psychology. doi: 10.1002/ijop.12380

Satir, V. (2016). Temel aile terapisi. İstanbul: Beyaz Yayınları.

Semerci, B. (2015). Birlikte büyütelim. İstanbul: Alfa Yayınları.

Skowron, E. A. (2005). Parent differentiation of self and child competence in low-1ncome urban families. Journal of Counseling Psychology, 52(3), 337.

Stipek, D., \& Green, J. (2001). Achivement motivation in early childhood: Cause for concern or celebration? S. Golbeck (Ed.), Psychological Perspectives On Early Childhood Education, 64-91. Mahwah, NJ: Erlbaum. 
Tracy, J.L., \& Robins, R. (2007). Emerging insights into natüre and function of pride. Current Directions in Psychological Science, 16, 147-150.

Verschueren, K., Marcoen, A., \&Schoefs, V. (1996). The internal working model of the self, attachment, and competence in five-year-olds. Child Development, 67, 2493-2511.

Verschueren, K.,Doumen, S., \& Buyse, E. (2012). Relationships with mother, teacher, and peers: unique and joint effects on young children's self-concept.Attachment \& Human Development, 14(3), 233-248.doi:10.1080/14616734.2012.672263

Woolfolk, A. E. (1998). Educational Psychology (7. Ed.). Boston: Allyn and Bacon.

Yavuzer, H.(2001). Yaygın ana-baba tutumları, ana-baba okulu (9. Bask1). Ankara:Remzi Kitabevi.

Yavuzer, H. (2016). Çocuk eğitimi el kitabı. İstanbul: RemziKitabevi.

Yavuzer, H. (2018). Ĕ̆itim ve gelişim özellikleriyle okul çağı çocuğu. İstanbul: Remzi Kitabevi.

Yörükoğlu, A. (2007). Değișen toplumda aile ve çocuk. Ankara: Özgür Yayınları.

\section{Extended Abstract}

\section{Purpose}

The way individuals perceive themselves facilitates their adaptation to the society they live in and it is effective in the development of the self-concept. Being a concept related to the social development, the self-concept is defined as the realization of what individuals themselves can do. The self-concept develops from early childhood and it is influenced by the attitudes of parents. When parents have a positive attitude, children perceive themselves better, can realize their qualifications and what they can do better, and express themselves more easily, in other words, the self-concept is positively influenced. From this point of view, the research study aims to examine the relationship between the parental attitudes and self-concept levels of pre-school children.

In the study, the correlational survey model, which is one of the general survey models, was used in order to examine the relationship between parental attitudes and self-concept of preschool children. The research group of the study was comprised of 201 preschool children and their parents who were selected voluntarily via the simple random sampling method from preschool education institutions functioning under the Provincial Directorate of National Education in Afyonkarahisar city center in the 2018-2019 academic year. "General Information Form", "Perception of Child Self-Concept-PCSC" that was developed by Villa and Auzmendi (1992), and "Parental Attitude Scale (PAS)" that was developed by Karabulut, Demir, and Şendil (2008) were used as the data collection tools. 
In the evaluation of the demographical features of the preschool teachers, descriptive statistics such as the frequency and percentage were used. In the analysis of the data obtained from the Perception of Child Self-Concept and Parental Attitude Scale, the Multilinear Regression Analysis was used in order to determine whether the dependent variable (self-concept) is predicted by the independent variables (parental attitudes).

\section{Results}

It was determined that the change in the self-concept scores of the preschool children predicted only .06 of the change in parental attitude scale sub-dimensions (Democratic Attitude, Authoritarian Attitude, Overprotective Attitude, and Permissive Attitude). The multiple regression results demonstrate that there is a significant relationship between the parental attitudes scale sub-dimensions and the self-concept scale $\left(\mathrm{R}=.250, \mathrm{R}^{2}=.062, \mathrm{p}<.05\right)$. Although this ratio is not high, in the self-concept scale scores; it is observed that it significantly and positively predicts the democratic attitude sub-dimension scores that is one of the parental attitude scale sub-dimensions, and it significantly and negatively predicts the overprotective attitude sub-dimension scores. It was determined that the other sub-dimensions did not predict the self-concept at significant levels.

\section{Discussion and Conclusion}

It is very important for children to interact with their environment. The parents are the first and foremost individuals for the children to interact from the moment they are born. The attitudes and behaviors of the parents towards their children play a big role in the growth of children, who spend their lives with their parents, as happy and confident individuals with a developed self-concept. This study was conducted to examine the relationship between parental attitudes and self-concept levels of preschool children. As the conclusion of the study, it is observed that parents with democratic attitudes positively predict the self-concept of their children, while the parents with overprotective attitudes negatively predict the selfconcept of their children. In other words, it can be mentioned that the self-concept levels of the children of parents with democratic attitudes are high; the self-concept levels of children of parents with overprotective attitudes are low. It is observed that there are previous studies supporting the obtained results.

The results of this study, those of previous studies, and some theories of development demonstrate that the parental attitudes are quite influential on the self-concept levels of children. It is because children are continuously in a family environment, and this family environment influences the self-concept levels of children in a positive or negative way. Since the children of parents with democratic attitudes are in a positive family system, it can be said that their self-concept levels are higher. As per the children of authoritarian parents, since they are continuously under the parent control and pressure, it can be thought that they have problems in expressing themselves and they have low levels of self-concept. It starts at early ages for the children to acquire positive self-concept. The acquisition of the self-concept is influenced by the attitudes of the parents with whom children coexist most. Therefore, it can be mentioned that parents should be in a positive attitude towards their children. 
In line with the results obtained from the study, following suggestions can be made:

- Children with low levels of self-concept can be detected and programs can be applied that will increase their self-concept levels.

- The change in the impact of parental attitudes on the self-concept acquisition levels of children can be monitored in the long term through longitudinal studies.

- The impact of parental attitudes can be examined on different skills together with the self-concept.

ETIK BEYAN: " Okul Öncesi Dönem Çocuklarının Benlik Kavramı ve Ebeveyn Tutumları Arasındaki İlişkinin Incelenmesi" başlıklı çalışmanın yazım sürecinde bilimsel, etik ve alıntı kurallarına uyulmuş; toplanan veriler üzerinde herhangi bir tahrifat yapılmamış, karşılaşılacak tüm etik ihlallerde "Mehmet Akif Ersoy Üniversitesi Eğitim Fakültesi Dergisi Yayın Kurulunun” hiçbir sorumluluğunun olmadı̆̆ı, tüm sorumluluğun Sorumlu Yazara ait olduğu ve bu çalışmanın herhangi başka bir akademik yayın ortamına değerlendirme için gönderilmemiş olduğunu taahhüt ederim." 